\title{
AKTIVITAS ANALGESIK EKSTRAK DAUN JARUM TUJUH BILAH (Pereskia Bleo K) PADA MENCIT JANTAN (Mus Musculus)
}

\author{
Novita Sari, Islamudin Ahmad, Laode Rijai \\ Laboratorium Penelitian dan Pengembangan FARMAKA TROPIS Fakultas Farmasi \\ Universitas Mulawarman, Samarinda, Kalimantan Timur \\ email: opie_mocca@yahoo.com
}

\begin{abstract}
ABSTRAK
Telah dilakukan penelitian dengan judul Aktivitas Analgesik Ekstrak Daun Jarum Tujuh Bilah (Pereskia bleo K) terhadap mencit jantan (Mus musculus). Penelitian ini bertujuan untuk mengetahui aktivitas analgesik ekstrak etanol $96 \%$ pada daun jarum tujuh bilah (Pereskia bleo $\mathrm{K}$ ) dengan berbagai tingkatan konsentrasi dalam mengurangi jumlah geliat yang ditimbulkan oleh induksi asam asetat $1 \%$ yang diberikan secara intraperitoneal kepada mencit metode induksi kimia (Siegmund) dan metode Hot Plate. Hewan uji yang digunakan sebanyak 30 ekor mencit putih jantan yang dibagi menjadi 5 kelompok perlakuan, masing-masing terdiri dari 3 ekor mencit putih jantan. Kelompok I diberikan CMC-Na $1 \%$ sebagai kontrol negatif. Kelompok II diberikan suspensi asetosal kontrol positif. Kelompok III, IV, V masing-masing diberi ekstrak etanol 96\% daun jarum tujuh bilah dengan dosis $0,78 \mathrm{mg} / 30 \mathrm{gBB}$ (dosis I), 7,8 mg/30 gBB (dosis II), dan $78 \mathrm{mg} / 30$ gBB (dosis III). Hasil penelitian menunjukkan pada metode Siegmund diperoleh \% proteksi sebesar $50 \%$ (dosis I), $60 \%$ (dosis II), dan $70 \%$ (dosis III). Sementara pada metode hotplate diperoleh hasil \% proteksi sebesar 98,3\% (dosis I), 98,9 \% (dosis II), dan 97,3 (dosis III). Berdasarkan hasil \% proteksi dapat disimpulkan bahwa ekstrak daun tujuh bilah memiliki aktivitas analgesik dan memenuhi syarat efektif sebagai analgesik dengan $\%$ proteksi $>50 \%$.
\end{abstract}

Kata Kunci: Analgesik, daun Jarum Tujuh Bilah (Pereskia bleo K), ekstrak etanol, nyeri buatan, mencit (Mus musculus).

\section{PENDAHULUAN}

Obat tradisional (herbal) telah diterima secara luas di hampir seluruh negara di dunia. Menurut World Health Organization (WHO), negara-negara di Afrika, Asia dan Amerika Latin menggunakan obat tradisional (herbal) sebagai pelengkap pengobatan primer yang mereka terima. Bahkan di Afrika, sebanyak $80 \%$ dari populasi menggunakan obat herbal untuk pengobatan primer (WHO, 2003). Analgesik atau obat-obat penghalang rasa nyeri adalah zat-zat yang mengurangi atau menghalau rasa nyeri tanpa menghilangkan kesadaran (Tjay dan Rahardja,2002). Salah satu tumbuhan obat tradisional yang berkhasiat sebagai analgesik adalah daun Jarum Tujuh Bilah (Pereskia bleo K). Daun Jarum Tujuh Bilah (Pereskia bleo K) secara empiris berkhasiat sebagai obat analgesik seperti nyeri, sakit kepala,sakit perut (nyeri menstruasi), dan sakit gigi di kalangan masyarakat Samarinda Kalimantan Timur (Hariana, 2006).

\section{METODE PENELITIAN}

\section{Bahan}

Bahan yang digunakan dalam penelitian adalah daun jarum tujuh bilah yang diperoleh dari Kota Samarinda, Etanol 96\%, Aquadest, Aspirin, Asam Asetat, dan Mencit Jantan 


\section{Peralatan}

Peralatan yang digunakan pada penelitian ini antara lain gelas kimia, labu ukur, cawan porselin, timbangan analitik, timbangan untuk menimbang mencit, batang pengaduk, sonde, sentrifuge, tabung reaksi, Hotplate.

\section{Penyiapan Sampel Uji}

Sampel Jarum Tujuh Bilah dipilih daun yang segar untuk dijadikan simplisia. Sampel tersebut dapat ditemukan di daerah pemukiman warga khususnya bagian Samarinda Ilir Kalimantan Timur.

\section{Prosedur Pengujian}

Pengujian ini menggunakan15 ekor mencit jantan yang di bagi ke dalam 5 Kelompok. Kelompok I (CMC-Na 1\%) : larutan CMC-Na sebagai kontrol negatif. Kelompok II asetosal (sebagai kontrol positif) yang disuspensi dalam CMC-Na $1 \%$. Kelompok III diberi ekstrak etanol dosis $0,78 \mathrm{mg} / \mathrm{gBB}$. Kelompok IV diberikan ekstrak etanol DJTB dengan dosis 7,8 mg/gBB. Kelompok V diberikan ekstrak etanol DJTB dengan dosis $78 \mathrm{mg} / \mathrm{gBB}$.

Metode Siegmund, setelah diberi perlakuan dosis tunggal peroral, 10 menit kemudian mencit diberi perangsang nyeri, yaitu asam asetat $1 \%$ secara i.p Kemudian diamati geliat yang terjadi, dihitung tiap 10 menit selama 60 menit dan geliat dihitung dengan rumus $\%$ proteksi.
Metode Hotplate, Sebelum mencit diberi perlakuan diletakkan mencit diatas hotplate panas dengan suhu $50-60^{\circ} \mathrm{C}$, tunggu hingga mencit mengangkat kaki sebagai waktu respon dan setelah diberi perlakuan diamati tingkah laku hewan uji (mencit) dengan mengangkat atau menjilat kakinya serta lompatan. Pengamatan dilakukan pada menit ke 10 , 20, 30, 40, 50 dan 60 menit.

\section{HASIL DAN PEMBAHASAN}

Penelitian ini dilakukan untuk mengetahui efek analgetika ekstrak etanol $96 \%$ daun jarum tujuh bilah hasil penyarian dengan metode maserasi terhadap mencit jantan putih.

Penetapan waktu pemberian asam asetat dilakukan untuk menentukan waktu yang paling optimal antara waktu pemberian obat dengan induksi nyeri. Orientasi waktu yang diberikan yaitu 10 , 20 dan 30 menit. Berdasarkan hasil orientasi selama 1 jam pengamatan, ternyata pada menit 10 mempunyai jumlah geliat yang berbeda bermakna ( $p$ $<0,05)$ dengan waktu 20 dan 30 menit. Dari hasil analisis tersebut bahwa pada menit ke 10 obat sudah mencapai onsetnya sehingga siap memberikan efek. Sehingga pemberian asam asetat dipilih 10 menit setelah pemberian Asetosal. Hasil pemberian dapat terlihat pada tabel 1.

Hasil jumlah geliat kumulatif mencit tiap 10 menit selama 1 jam dapat dilihat pada tabel 2 .

Tabel 1. Jumlah Geliat Kumulatif Mencit Pada Waktu Pemberian Asam Asetat

\begin{tabular}{ccccc}
\hline $\begin{array}{c}\text { Waktu } \\
\text { (menit) }\end{array}$ & \multicolumn{3}{c}{ Jumlahgeliatkumulatif } & \multirow{2}{*}{ Rata-rata } \\
\cline { 2 - 4 } 0 & 1 & 2 & 3 & - \\
10 & - & - & - & 63 \\
20 & 58 & 67 & 64 & 131,33 \\
30 & 125 & 130 & 139 & 122,67 \\
\hline
\end{tabular}


Tabel 2. Jumlah geliat dan persen proteksi kumulatif mencit tiap 10 menit selama 1 jam setelah perlakuan ekstrak etanol $96 \%$ DJTB

\begin{tabular}{|c|c|c|c|c|c|}
\hline \multirow{2}{*}{$\begin{array}{l}\text { Kelompok } \\
\text { perlakuan }\end{array}$} & \multicolumn{3}{|c|}{$\begin{array}{l}\text { Jumlah geliat kumulatif mencit } \\
\text { tiap } 10 \text { menit selama } 1 \text { jam }\end{array}$} & \multirow{2}{*}{$\begin{array}{l}\text { Rata-rata } \\
\text { geliat }\end{array}$} & \multirow{2}{*}{$\begin{array}{c}\text { Persen }(\%) \\
\text { Proteksi }\end{array}$} \\
\hline & 1 & 2 & 3 & & \\
\hline $\begin{array}{l}\text { Kontrol negatif } \\
(\mathrm{Na} \mathrm{CMC} 1 \%)\end{array}$ & 25 & 29 & 36 & 30 & 0 \\
\hline $\begin{array}{l}\text { Kontrol Positif } \\
\quad \text { (asetosal) }\end{array}$ & 13 & 17 & 15 & 15 & $50 \%$ \\
\hline $\begin{array}{c}\text { Dosis I } \\
(0,78 \mathrm{mg} / 30 \mathrm{gBB})\end{array}$ & 19 & 12 & 14 & 15 & $50 \%$ \\
\hline $\begin{array}{c}\text { Dosis II } \\
(7,8 \mathrm{mg} / 30 \mathrm{gBB})\end{array}$ & 10 & 17 & 10 & 12 & $60 \%$ \\
\hline $\begin{array}{c}\text { Dosis III } \\
(78 \mathrm{mg} / 30 \mathrm{gBB})\end{array}$ & 11 & 8 & 9 & 9 & $70 \%$ \\
\hline
\end{tabular}

Tabel 3 Jumlah geliat dan persen proteksi kumulatif mencit tiap 10 menit selama 1 jam setelah perlakuan ekstrak etanol 96\% DJTB metode Hotplate

\begin{tabular}{|c|c|c|c|c|c|}
\hline \multirow{2}{*}{$\begin{array}{c}\text { Kelompok } \\
\text { perlakuan }\end{array}$} & \multicolumn{3}{|c|}{$\begin{array}{l}\text { Jumlah lompatan kumulatif mencit } \\
\text { tiap } 10 \text { menit selama } 1 \text { jam }\end{array}$} & \multirow{2}{*}{$\begin{array}{l}\text { Rata-rata } \\
\text { lompatan }\end{array}$} & \multirow{2}{*}{$\begin{array}{c}\text { Persen }(\%) \\
\text { Proteksi }\end{array}$} \\
\hline & 1 & 2 & 3 & & \\
\hline $\begin{array}{l}\text { Kontrol negatif } \\
(\mathrm{Na} \mathrm{CMC} 1 \%)\end{array}$ & 178 & 185 & 186 & 183 & - \\
\hline $\begin{array}{l}\text { Kontrol Positif } \\
\quad \text { (asetosal) }\end{array}$ & 121 & 93 & 105 & 105 & 42,7 \\
\hline $\begin{array}{c}\text { Dosis I } \\
(7,8 \mathrm{mg} / 30 \mathrm{gBB})\end{array}$ & 3 & 3 & 2 & 3 & 98,3 \\
\hline $\begin{array}{c}\text { Dosis II } \\
(5,2 \mathrm{mg} / 20 \mathrm{gBB})\end{array}$ & 2 & 3 & 2 & 2 & 98,9 \\
\hline $\begin{array}{c}\text { Dosis III } \\
(52 \mathrm{mg} / 20 \mathrm{gBB})\end{array}$ & 5 & 5 & 4 & 5 & 97,3 \\
\hline
\end{tabular}

Hasil tabel 2 menunjukkan bahwa perlakuan Asetosal dan perlakuan ekstrak etanol daun Jarum Tujuh Bilah dosis I, II dan III dapat menurunkan geliat mencit hingga berkurang lebih dari $50 \%$ disbanding control negatif, ini berarti perlakuan Asetosal dan ekstrak etanol pada dosis I, II, dan III mempunyai efek analgetika. Sedangkan pada perlakuan ekstrak etanol dosis I menunjukkan penurunan geliat mencit $50 \%$ dibanding control negatif, ini berarti pada dosis tersebut tidak mempunyai aktifitas sebagai analgesik. Suatu obat dikatakan mempunyai aktifitas sebagai analgetsik bila mampu menurunkan jumlah geliat mencit sebesar $>50 \%$ dari jumlah geliat pada kelompok control negatif (Anonim, 1991).

Dari data jumlah geliat kumulatif mencit masing-masing kelompok perlakuan selanjutnya dibuat $\%$ proteksi, hasil dapat dilihat pada tabel 2. Tabel 2 menunjukkan bahwa setiap kelompok perlakuan menunjukkan \% proteksi yang berbeda-beda pada tiap peringkat dosisnya. Persentase rata-rata tertinggi pada $70 \%$ yaitu dosis ke-III. Persentase proteksi rata-rata dari $50 \%$ dibanding 
kontrol negatif pada $50 \%$ yaitu dosis keI. Pada dosis ke- II ekstrak etanol daun Jarum Tujuh Bilah positif sebagai analgetsik karena $\%$ proteksinya $>50 \%$.

Pengujian efek analgesik dengan tes plat panas bertujuan untuk mengetahui potensi efek analgesik daun Jarum Tujuh Bilah pada rangsangan panas yang akut. Hewan coba yang diletakkan di atas plat panas akan bereaksi terhadap stimulus nyeri dengan cara mengangkat, menjilat kaki depan atau meloncat dengan selang waktu antara pemberian stimulus dengan reaksi yang muncul dari mencit disebut sebagai waktu reaksi. Metode ini dengan menggunakan hotplate yang suhunya 50$55^{\circ} \mathrm{C}$. Hasil perlakuan metode Hotplate dapat dilihat pada tabel 3.

Data hasil penelitian efek analgesik ekstrak etanol daun Jarum Tujuh Bilah memiliki efek analgesik menunjukkan bahwa pemberian oral ekstrak etanol 96\% daun Jarum Tujuh Bilah dosis I $(7,8 \mathrm{mg} / 30 \mathrm{gBB})$, dosis II $(5,2 \mathrm{mg} / 20 \mathrm{gBB})$, dosis III $(52 \mathrm{mg} /$ 20gBB) memberikan efek analgetik terhadap rangsangan nyeri yang diinduksi oleh stimulasi panas. Efek analgesik yang ditimbulkan diduga akibat penghambahatan keluarnya mediator inflamasi atau penghambatan aktivitas siklooksigenase.

Suatu obat dikatakan mempunyai aktifitas sebagai analgesic bila mampu menurunkan jumlah lompatan mencit sebesar $>50 \%$ dari jumlah geliat pada kontrol negatif (Anonim, 1991). Pada metode Hotplate timbulnya rasa nyeri pada hewan coba (mencit jantan) ditandai dengan adanya lompatan. Dari data jumlah geliat kumulatif mencit masing-masing kelompok perlakuan yang selanjutnya dibuat $\%$ proteksi, hasilnya dapat dilihat pada tabel 5.4 bahwa jumlah lompatan pada tiap dosis berbeda-beda, ekstrak etanol daun jarum tujuh bilah masing-masing dosis memiliki aktifitas sebagai analgetika karena $\%$ proteksi $>50 \%$ serta efektif sebagai analgetika dari metode tersebut. Kejadian nyeri memiliki sifat yang unik pada setiap individual bahkan jika cedera fisik tersebut identik pada individual lainnya. Adanya takut, marah, kecemasan, depresi dan kelelahan akan mempengaruhi bagaimana nyeri itu dirasakan. Subjektifitas nyeri membuat sulinya mengkategorikan nyeri dan mengerti mekanisme nyeri tersebut (Anonim, 1991).

\section{KESIMPULAN}

a. Ekstrak etanol $96 \%$ daun Jarum Tujuh Bilah (Pereskia bleo K) memiliki aktivitas sebagai analgetika terhadap mencit jantan (Mus musculus)

b. Dosis efektif ekstrak etanol 96\% daun Jarum Tujuh Bilah (Pereskia bleo $\mathrm{K}$ ) terhadap mencit jantan (Mus musculus) dengan metode Siegmund adalah dosis $78 \mathrm{mg} / 30 \mathrm{gBB}$ dan metode Hotplate yaitu dosis 5,2 $\mathrm{mg} / 20 \mathrm{gBB}$.

c. Ekstrak etanol $96 \%$ daun Jarum Tujuh Bilah (Pereskia bleo K) efektif sebagai analgetika terhadap mencit jantan (Mus musculus)

\section{DAFTAR PUSTAKA}

1. Anief. M, 1995, Prinsip Umum dan Dasar Farmakologi. Gadjah Mada University Press; Yogyakarta

2. Goodman and Gilman. 2006. The Pharmacological Basis Of Therapeutics $11^{\text {th }}$. Ed. New York: Macmillan Publ.Co

3. Julianti, F. 2009. Manfaat Tumbuhan Jarum Tujuh Bilah (PereskiaK ) sebagai agen anti bacterial terhadap bakteri gram positif dan negatif. JKKI; Yogyakarta

4. Mutschler, E., 1995, Analgetika Dalam Dinamika Obat, Diterjemahkan oleh Widianto, M. B., dan Ranti, A. S., Edisi V, Penerbit ITB; Bandung. 
5. Rosadiani Hefira. 2009. Efek Analgesik Ekstrak Air dan Ekstrak Etanol Asam Jawal Tamarindusindica L) Pada Mencit dengan Induksi Thermal. Fakultas Kedokteran Universitas Kristen Maranatha; Bandung.
6. Winarto, W.P dan Tim Karyasari. 2003. Jarum Tujuh Bilah Budidaya dan Pemanfaatan Untuk Obat. Penerbit Swadaya; Jakarta. 